\title{
INTRODUCTION
}

\section{THE 2000 RADIOCARBON VARVE/COMPARISON ISSUE}

Johannes van der Plicht, guest editor

Centre for Isotope Research, Radiocarbon Laboratory, Groningen University, Nijenborgh 4, 9747 AG Groningen, the Netherlands. Email: plicht@phys.rug.nl.

For radiocarbon calibration, the arrow of time is pointing backwards but the entropy does not necessarily decrease in this direction...

At the 16th International Radiocarbon Conference in Groningen, June 1997, it was decided to publish the 3rd calibration issue (Stuiver and van der Plicht, editors 1998). Upon amending and extending previous calibration issues (Stuiver and Kra 1986; Stuiver et al. 1993), a new and recommended calibration curve INTCAL98 has been constructed (Stuiver et al. 1998).

Calibration is the conversion of radiocarbon ages (BP) into historical ages (cal BC, cal AD, or cal BP). The ${ }^{14} \mathrm{C}$ content of the atmosphere is not a natural constant throughout the ages, but depends on factors such as geomagnetic field intensity and solar fluctuations (directly influencing the cosmic ray flux and thus the ${ }^{14} \mathrm{C}$ production rate in the atmosphere), and carbon reservoir reorganizations (mainly $\mathrm{CO}_{2}$ exchange ocean/atmosphere) (Bard 1998). Past atmospheric ${ }^{14} \mathrm{C}$ fluctuations are known by measuring the ${ }^{14} \mathrm{C}$ content of samples which are dated by other means, i.e. independent of ${ }^{14} \mathrm{C}$, and preferably absolute.

The INTCAL98 calibration curve is based on the following such records:
a). tree rings measured by both ${ }^{14} \mathrm{C}$ and dendrochronology (absolute);
b). tree rings measured by both ${ }^{14} \mathrm{C}$ and dendrochronology (floating);
c). corals dated by both ${ }^{14} \mathrm{C}$ and $\mathrm{U}$-series decay;
d). high resolution marine varves dated by ${ }^{14} \mathrm{C}$.

The following remarks can be made concerning the selection of these records:

Ad a). Strictly speaking, only this part is a true calibration curve since dendrochronology is the only dating method which is absolute. This part of the calibration curve is the product of high-resolution ${ }^{14} \mathrm{C}$ measurements on mainly German Oak, Irish Oak, US Bristlecone and US Douglas Fir. These measurements have been performed during the last decennia by several laboratories (Belfast, Heidelberg, Pretoria, Seattle, Tucson, and Groningen), using high precision conventional dating and mutual cross-checking. The absolute tree ring chronology yields a calibration curve, now reaching back to $8329 \mathrm{cal} \mathrm{BC}$ (Kromer and Spurk 1998; Stuiver et al. 1998).

Ad b). A 1900-yr-long floating chronology for German pine trees is matched (using the ${ }^{14} \mathrm{C}$ measurements) to the absolute tree ring chronology, extending the calibration record back to $9908 \mathrm{cal}$ BC (Kromer and Spurk 1998). The uncertainty of the match is about 20 calendar years.

Ad c). For the Late Glacial and Deglaciation periods, beyond the tree-ring limit, corals are used for calibration purposes. The record consists of paired measurements ${ }^{14} \mathrm{C}$ vs. U-series dating (Bard et al. 1998; Burr et al. 1998). This record extends the INTCAL98 calibration curve back to $15,585 \mathrm{cal}$ BP. Contrary to tree rings which are atmospheric, the coral record is marine so the calibration curve beyond the tree ring limit is "marine derived". 
One has to be aware of the following constraints using these data:

1. Concerning ${ }^{14} \mathrm{C}$ dating: Because the coral part of the curve is marine, there is a "reservoir effect" correction. For INTCAL98, this reservoir age is taken as 400 and $500 \mathrm{yr}$ for times younger and older than 10,000 cal BP, respectively. These are very reasonable numbers, but it remains an assumption. Furthermore, reservoir ages are now known to be significantly larger during Late Glacial and Glacial times, at least in the Southwest Pacific (Sikes et al. 2000). As another additional possible complication, rapid atmospheric ${ }^{14} \mathrm{C}$ fluctuations are damped by the ocean.

2. Concerning U/Th dating: the U-series dates are a result of a measurement, which is different from dendrochronology which is simply based on tree-ring counting. The measurements are considered reliable and understood, but are by definition not absolute.

Ad d). ${ }^{14} \mathrm{C}$ measurements for material from laminated sediments (varves) yield floating chronologies, which have to be matched to the calibration curve. Such measurements from the Cariaco basin (Hughen et al. 1998a, 1998b), as an exception to the rule, are included in INTCAL98 because it did strengthen the tree-ring/coral link considerably. The assumptions here are again 1) the marine reservoir correction for ${ }^{14} \mathrm{C}$, and 2 ) the accuracy of varve counting.

All together, INTCAL98 was and is the calibration curve recommended for general use until further notice, taking the above mentioned constraints into account. The INTCAL98 curve covers the time from the present back to $13,635 \mathrm{cal} \mathrm{BC}$ (15,585 cal BP). Back to 24,000 cal BP there are more paired ${ }^{14} \mathrm{C} / \mathrm{U}$-series datapoints from the corals available (Bard et al. 1998). Also, the coral record includes two datapoints at around 30,000 and 40,000 cal BP. This resolution, however, is too low in order to call the part beyond 15,585 cal BP a "calibration curve". In addition, there are conflicting records for this time range (as discussed below and in several papers of the present issue).

Calibration information is based on paired measurements of ${ }^{14} \mathrm{C}$ versus another independent dating method. Apart from the tree rings and corals which form the basic dataset for INTCAL98, there are several other dating methods which can be compared with ${ }^{14} \mathrm{C}$, and which are not included in INTCAL98 for a variety of reasons discussed below. We can make the following inventory:

a). Laminated ("varved") sediments which contain ${ }^{14} \mathrm{C}$ datable material

b). Speleothems dated by both ${ }^{14} \mathrm{C}$ and U-decay series

c). Radiocarbon versus Thermoluminescence (TL)

d). Radiocarbon versus ${ }^{40,39} \mathrm{Ar}$ isotope dating, ESR, OSL, AAR

e). Isolated (Late Glacial) floating trees measured by ${ }^{14} \mathrm{C}$

f). Reconstructions, i.e. not the comparison ${ }^{14} \mathrm{C}$ versus another dating measurement but versus a reconstructed timescale.

These records have not been included in INTCAL98. The reason is-in general-conflicts between records which are not (yet) resolved. Several "calibration curves" could be constructed, differing up to many millennia during Glacial times. Nevertheless there is a wealth of important information on ${ }^{14} \mathrm{C}$ variations in the past available in these records, several now covering the complete ${ }^{14} \mathrm{C}$ dating range. Therefore it was decided to dedicate a special issue of the Radiocarbon Journal to these datasets (Stuiver and van der Plicht 1998).

The following remarks can be made concerning these datasets:

Ad a). Varved records. Laminated sediments yielding varve chronologies are only absolute when they extend to the present and when the laminations are truly annual. But all varve chronologies are floating and thus have to be matched to the calibration curve; counting of laminations is quite often 
problematic. Revisions had to be made quite often in the past (see e.g. Wohlfarth 1996). Annual layer identification can be a personal affair, and there can be hiatuses in the sediment. Individual chronologies are not internally checked like tree rings, where missing or double rings can be identified by cross-dating. In addition, reservoir effects have to be reconciled for marine or lacustrine sediments.

Ad b). Speleothems. Calibration work based on dating speleothems depends on assumptions for both methods. For ${ }^{14} \mathrm{C}$ there is the reservoir effect: the initial conditions of fossil carbon has to be known, and this reservoir correction is assumed constant throughout time. For U/Th, the initial ${ }^{230} \mathrm{Th}$ present during speleothem growth has to be known (Beck et al. 2000). Furthermore there can be periods of reduced growth (Vogel and Kronfeld 1997).

Ad c). TL. The practical use of TL for calibration purposes is limited because of the large error bars for this method. Nevertheless, for the Glacial part useful ${ }^{14} \mathrm{C} / \mathrm{TL}$ comparisons were made (Barbetti 1980).

Ad d). Other. These techniques have been used only incidental, and the use is limited for the same reason as TL (large errors). Only mentioned here for completeness reasons. Details concerning Electron Spin Resonance (ESR) dating, Optically Stimulated Luminescence (OSL) dating and dating by Amino Acid Racemization (AAR) are described in textbooks like Aitken 1990.

Ad e). Floating trees. Isolated trees beyond the present INTCAL98 limit (9908 cal BC) are known, and in some cases ${ }^{14} \mathrm{C}$ measurements are done. These data can be matched to the calibration curve (the marine derived coral part), or to a high resolution laminated sediment. This might yield information on past atmospheric ${ }^{14} \mathrm{C}$ levels, or on the magnitude of the marine reservoir effect. Examples are Kromer et al. (1998) using tree ring sections around 11,500 BP (Allerød) and 15,000 BP, and Miramont et al. (this issue).

Ad f). Reconstructions. ${ }^{14} \mathrm{C}$ "calibration curves" can be reconstructed by linking series of ${ }^{14} \mathrm{C}$ measurements to archives such as ice cores and pollen sequences.

Voelker et al. (1998; this issue) use ${ }^{14} \mathrm{C}$ and ${ }^{18} \mathrm{O}$ from marine sediment foraminifera. The ${ }^{18} \mathrm{O}$ shows $\mathrm{D} / \mathrm{O}$ cycles which could be linked to the same signals in the GISP2 ice core, so that the GISP2 timescale can be used as a "calibrated timescale" for the ${ }^{14} \mathrm{C}$ measurements.

Sediments with a ${ }^{14} \mathrm{C}$ time/depth relation have been used to reconstruct "calibration curves". This can be done when (absolute) time markers are identified, like clear boundaries between pollen zones. As an example for the Late Glacial/Early Holocene, see Zbinden et al. 1989. This is not further discussed in this issue.

The records not included in INTCAL98 are brought together in this issue, except some records which have been published recently before in this journal (Geyh and Schlüchter 1998; Vogel and Kronfeld 1997) or which will be published elsewhere (Beck et al. 2000). At the Groningen Radiocarbon conference, there was the question "to varve or not to varve" for the construction of INTCAL98. It was decided to bring together the varve chronologies and the calibration related information from these records. Later, it was decided to expand the issue in order to include also non-varved records (as mentioned in the list above), so that a more appropriate name now is "comparison issue".

The first varve chronologies used for ${ }^{14} \mathrm{C}$ calibration purposes where the Swedish varves (Tauber 1970) and varves from Lake of the Clouds in Minnesota, USA (Stuiver 1970). At that time, dendrochronologically based ${ }^{14} \mathrm{C}$ calibration curves were limited in timescale, and the varved records gave unique information on Late Glacial atmospheric ${ }^{14} \mathrm{C}$ variations (Stuiver et al. 1986). The ${ }^{14} \mathrm{C}$ mea- 
surements were conventional, and not very detailed. After the introduction of AMS it became possible to obtain detailed varve chronologies by measuring material from individual laminationsincluding pollen, macrofossils, branches and insects. During the last decade, new or revised varve/ ${ }^{14} \mathrm{C}$ chronologies were obtained for Sweden/Scandinavia (Wohlfarth 1996), Holzmaar/Germany (Hajdas 1995), Soppensee/Switzerland (Hajdas 1993), Lake Gościąż/Poland (Goslar 1998) and Lake Suigetsu/Japan (Kitagawa and van der Plicht 1998a, 1998b). All these records are represented in this issue with either an overview of existing data, revisions and/or new measurements added. A new varve $/{ }^{14} \mathrm{C}$ record from Meerfelder Maar (Germany) is presented in this issue as well.

There are no new additional data for the coral records constituting INTCAL98 (Bard et al. 1998; Burr et al. 1998). A new dataset for corals measured by both ${ }^{14} \mathrm{C}$ and $\mathrm{U} / \mathrm{Th}$ is presented by Yokoyama et al. (this issue).

Finally, a few remarks concerning terminology. First there is the mystery of the word "calibration". Calibration per definition is the conversion of a measurement (in our case, the measurement of a ${ }^{14} \mathrm{C}$ date expressed in BP) into something absolute-truly absolute, thus actually only dendrochronology qualifies for this purpose. The end product of calibration is then a historical date (or better, a probable date range as produced by the calibration software) in cal BC or cal AD (Mook 1986). Sometimes cal $\mathrm{BP}$ is used, being calibrated (or calendar) years before the ${ }^{14} \mathrm{C}$ standard year $1950 \mathrm{AD}$ : cal $\mathrm{BP}=1950$ - cal AD = $1949+$ cal BC. Unfortunately, this time unit is also commonly used for chronologies like ice-cores (both the ice layer counted parts and the modeled age part), for U/Th dating, varve counting, TL dating, etc. But actually this "calibrated" timescale is not truly absolute, but the result of a measurement or a match. In addition, cal BP is not well defined-for example, it is not clear whether the $\mathrm{U}$-series dates are corrected for decay (using $\mathrm{T}_{\text {measurement }}-1950$ ); and sometimes the reference year is not chosen as 1950. This is not unlike the "absolute ages aren't exactly" discussion in geochronology (Renne et al. 1998). Throughout this issue, we use BP for the ${ }^{14} \mathrm{C}$ timescale (or ka BP, meaning thousands BP) and cal BP (or ka cal BP) for the calendar time scale.

In many plots of BP $\left({ }^{14} \mathrm{C}\right.$ method) versus cal $\mathrm{BP}$ (other method) the errors or assumptions in cal BP are not shown. Such errors can be quite significant (see Figure 1). One has to be aware that this can be misleading since cal BP suggests an absolute scale. Moreover, confusion is prone to emerge when the $\mathrm{BP} / \mathrm{cal} \mathrm{BP}$ numbers are transferred into ${ }^{14} \Delta$. Increased atmospheric ${ }^{14} \mathrm{C}$ levels show up as peaks in ${ }^{14} \Delta$. Such peaks can easily appear or disappear when the cal BP number is changed: excursions in ${ }^{14} \Delta$ strongly depend on the absolute value. Since the chronologies for the Glacial period discussed in this issue differ considerably (by several millennia towards the end of the ${ }^{14} \mathrm{C}$ time range), one has to be careful stating conclusions. For instance, in Archaeological discussions about the Upper/Middle Paleolithic chronologies, it seems that everybody is looking for a proposed synchronization between ${ }^{14} \mathrm{C}$ and TL or other dating technique (Bar Yosef 2000; van Andel 1997). This plays a role in the Neanderthal/human interference discussion (Mellars et al. 1999).

I would also advocate more respect for the term "calibration curve". Given the fact that by the strict definition the ${ }^{14} \mathrm{C}$ calibration curve is based on absolute dates, calibration curves cannot be different in principle. Nevertheless, very different "calibration curves" are produced—see e.g. Vogel and Kronfeld (1997), and as is apparent in this issue alone. Perhaps it is better to use the term "comparison curve".

A survey of comparison measurements other than varves, new (this issue) and old (literature survey), shows large variations - up to many millennia for the Glacial part $(>\approx 20 \mathrm{ka})$. It is illustrative to plot paired ${ }^{14} \mathrm{C} /$ "other method" (BP vs. cal BP) for all data available to date. For clarity, the data are divided into two figures (Figures 1a, 1b) and compared with the "equiline" (cal BP $=1950-\mathrm{cal}$ AD). 

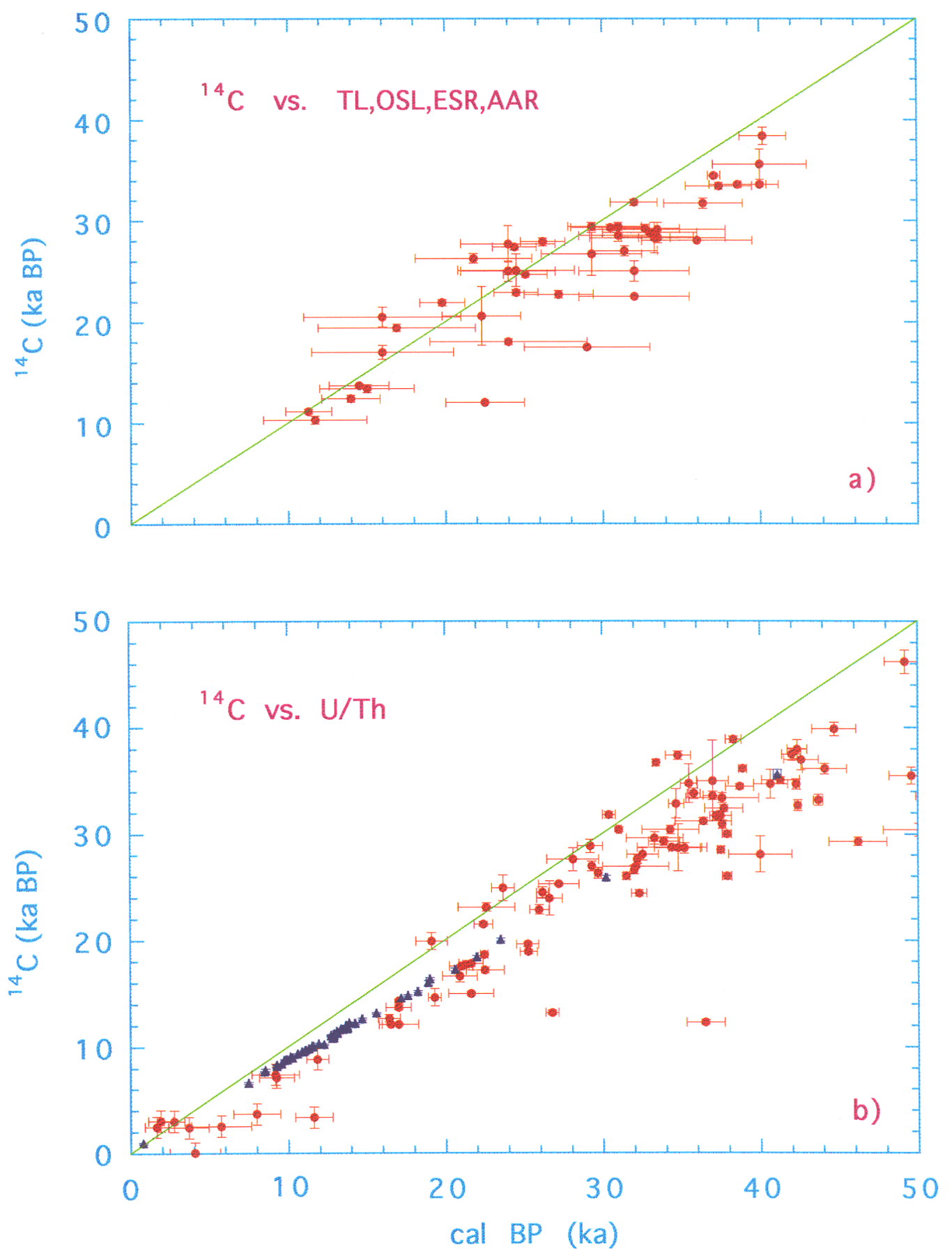

Figure 1 Compilation: comparison of ${ }^{14} \mathrm{C}$ versus other dating methods. a: TL, OSL, ESR, and AAR. b: U/Th dating. 


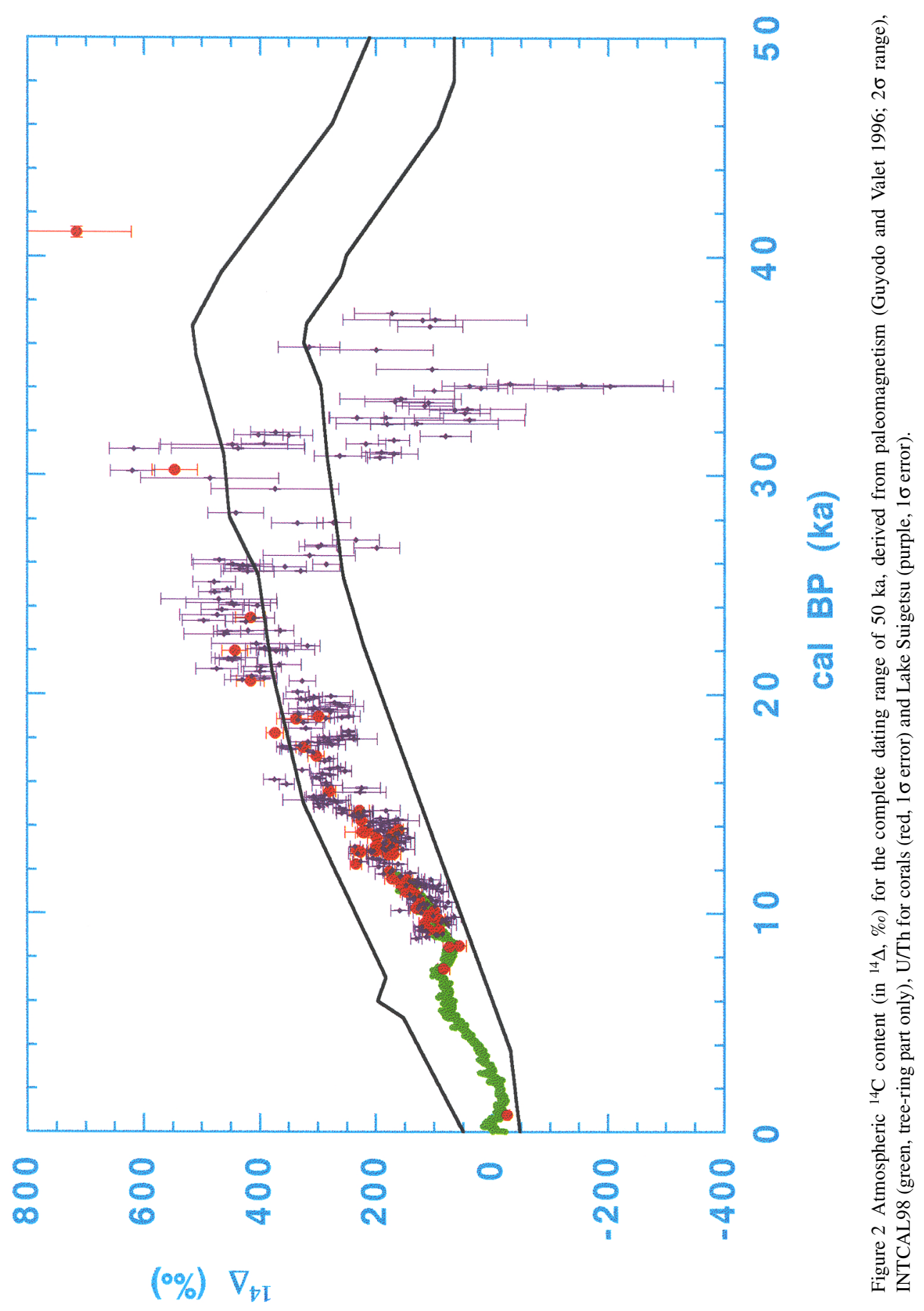


Figure 1a shows ${ }^{14} \mathrm{C}$ versus (mostly) TL as published over the years in a variety of studies (Barbetti 1980; Mellars 2000; Richter et al. 2000; Huxtable and Aitken 1977; Prescott and Smith 1993; Bell 1991; Zhu et al. 1999; Readhead 1988; Roberts et al. 1990). Single datapoints for OSL (Abeyratne et al. 1997), ESR (Mellars 2000), AAR (Farrand 1994) and ${ }^{39 / 40}$ Ar (Geyh and Schlüchter 1998) are shown here as well.

Figure 1b shows ${ }^{14} \mathrm{C}$ versus U/Th taken from: a). the literature (Bischoff et al. 1994; Chappell and Veeh 1978; Geyh and Schlüchter 1998; Holmgren et al. 1994; Lin et al. 1996; Lin et al. 1998; Lomitschka and Mangini 1999; Vogel and Kronfeld 1997), b). this issue (Goslar et al.; Stein et al.; Yokoyama et al.) and c). the "reference dataset" of coral calibration data (Bard et al. 1998). We note that in Figure $1 b$, measurements with quoted errors $>2500 \mathrm{yr}(1 \sigma)$ are omitted. The only conclusion one can draw from this compilation is that (apart from the coral dataset) the records deviate to strongly from each other to yield anything like a "calibration/comparison curve". Clearly, the assumptions underlying each particular method (as discussed above) has to be further investigated. In any case, calibration can not be done by interpolating between a few coral datapoints (Bard et al. 1998).

Figure 2 shows a comparison plot in terms of ${ }^{14} \Delta$. The "band" (between the two black solid lines) shows the range of atmospheric ${ }^{14} \mathrm{C}$ values calculated from paleomagnetic stack measurements (Guyodo and Valet 1996). Note that the two black solid lines correspond to $2 \sigma$ errors. Similar ${ }^{14} \Delta$ yields result from calculations of cosmogenic radionuclide production, derived from stacked ${ }^{10} \mathrm{Be}$ deposition rates (Frank 2000). Bard (1997) discusses these cosmic trends.

A selection of calibration/comparison data is shown in Figure 2; the errors for these data are $1 \sigma$. In green, the dendrochronological part of INTCAL98 (Stuiver et al. 1998) is plotted, in red, the coral dataset of Bard et al. (1998), and in purple, the updated dataset for the Lake Suigetsu varves (Kitagawa and van der Plicht, this issue). Perhaps this figure can be regarded as the present state-of-theart. The mean geomagnetic field intensity describes the general trend of the atmospheric ${ }^{14} \mathrm{C}$ variations very well. The tree rings (green), corals (red) and Japanese varves (purple) back to about $20 \mathrm{ka}$ cal BP follow this trend. Going to older ages no detailed "calibration curve" conclusions can be made. In this figure only the varves from Lake Suigetsu are shown because it is the only detailed terrestrial (atmospheric) record available to date in this time range. Note that the error in cal BP (not shown) is estimated as 2000 years (Kitagawa and van der Plicht 1998a). Beyond $30 \mathrm{ka}$ cal BP, fluctuations in ${ }^{14} \Delta$ are shown in conflict with the general geomagnetic trend. The large peak at $31 \mathrm{ka}$ cal BP is attributed to a magnetic excursion (Kitagawa and van der Plicht 1998a). Such excursions (known as Mono Lake and/or Laschamp; see also the discussion by Voelker et al. in this issue) have also been observed in other cosmogenic isotope records: ${ }^{10} \mathrm{Be}$ in the ice cores Vostok (at $35 \mathrm{ka}$, Raisbeck et al. 1987) and GRIP (at $41 \mathrm{ka}$, Yiou et al. 1997), ${ }^{10} \mathrm{Be}$ in marine sediments from the Mediterranean Sea (at $37 \mathrm{ka}$, Castagnoli et al. 1995), Gulf of California (at $32 \mathrm{ka}$, McHargue et al. 1995) and Caribbean Sea (at $37 \mathrm{ka}$, Aldahan and Possnert 1998), and ${ }^{36} \mathrm{Cl}$ in the GRIP ice core (at $38 \mathrm{ka}$, Baumgartner et al. 1998; at $32 \mathrm{ka}$, Wagner et al. 2000). Obviously there is a lot of room for discussion here concerning the "absolute" timescale cal BP, and the caution mentioned above concerning the influence of this timescale on peaks in the ${ }^{14} \Delta$ signal is repeated here. Also new records show cosmogenic peaks, at different times and sometimes with extremely large amplitudes (Beck et al. 2000).

The work presented in this issue should be qualified as "work in progress". It is obvious that this is in particular true for the Glacial period $>25 \mathrm{ka}$, where records strongly deviate from each other. What is needed is a new record, independent, terrestrial and with high resolution, to provide true atmospheric ${ }^{14} \Delta$ values. 
No recommendations can yet be made as to the use of a particular calibration (comparison) curve at this stage beyond INTCAL98. However, consensus seems to be emerging for the Deglaciation and Late Glacial parts of the ${ }^{14} \mathrm{C}$ dating range. For example, with new data from the Cariaco basin, a 400yr reservoir correction seems better now than the 500 used for INTCAL98 (Southon et al. 2000). This results in an excellent agreement between Cariaco and Lake Suigetsu for the Deglaciation.

We expect small revisions of INTCAL for this time period sometime in the near future. We may look forward to proposals or decisions at the next Radiocarbon conference in Wellington.

... time flies! ...

\section{NOTES}

1. Compiled from textbooks and encyclopedia:

varve: a distinctive, thin annual sedimentary layer, the lower part consisting of coarser, lighter colored clay and silt that was deposited in summer, and the upper of a finer-grained, darker clay deposited in winter. Numerous successive varves accumulated in temporary lakes near melting glaciers. Thicker and thinner varves at different places can be matched like tree rings.

Glacial melting is not the only cause of varves; in non-glacial lakes seasonal variation in accumulation of organic detritus may also give rise to annual laminations, as well as seasonal variation in sedimentation and chemical precipitation.

The word "varve" comes from Sweden—varv means as well a circle as a periodical iteration of layers (de Geer 1912).

2. Perhaps superfluous but useful for reasons of clarity we give here the definition of ${ }^{14} \Delta$ (expressed in BP and cal BP)

$$
{ }^{14} \Delta=[\exp (-\mathrm{BP} / 8033) \times \exp (\mathrm{cal} \mathrm{BP} / 8267)-1] \times 1000(\% \circ) .
$$

Note that this corresponds to ${ }^{14} \delta_{N}^{i}$ as proposed by Mook and van der Plicht (1999).

- $\mathrm{BP}=$ conventional ${ }^{14} \mathrm{C}$ age, i.e. activity measured relative to the Oxalic Acid standard and corrected for isotopic fractionation to ${ }^{13} \delta=-25 \%$.

- cal BP = historical date with respect to $1950 \mathrm{AD}$

- physical half-life 5730 year: $\mathrm{T}_{1 / 2} / \ln 2=8267$

- conventional half-life 5568 year: $\mathrm{T}_{1 / 2} / \ln 2=8033$

\section{From Webster's Dictionary:}

calibrate: to fix, check or correct the graduations of a measuring instrument. compare: to examine, in order to observe or discover similarities or differences.

\section{REFERENCES}

Abeyratne M, Spooner NA, Grün R, Head J. 1997. Multidating studies of Batadomba cave, Sri Lanka. Quaternary Science Reviews 16:243-55.

Aitken M. 1990. Science based dating archaeology. UK: Longman House.

Aldahan A, Possnert G. 1998. A high resolution ${ }^{10} \mathrm{Be}$ profile from deep sea sediment covering the last $70 \mathrm{ka}$ : indication for globally synchronized environmental events. Quaternary Geochronology 17:1023-32.

Barbetti M. 1980. Geomagnetic strength over the last 50,000 years and changes in atmospheric ${ }^{14} \mathrm{C}$ concentration: emerging trends. Radiocarbon 22(2):192-9.

Bard E. 1997. Nuclide production by cosmic rays during the Last Ice Age. Science 277:532-3. 
Bard E. 1998. Geochemical and geophysical implications of the radiocarbon calibration. Geochimica et Cosmochimica Acta 62:2025-38.

Bard E, Arnold M, Hamelin B, Tisnerat-Laborde N, Cabioch G. 1998. Radiocarbon calibration by means of mass spectrometric ${ }^{230} \mathrm{Th} /{ }^{234} \mathrm{U}$ and ${ }^{14} \mathrm{C}$ ages of corals: an updated database including samples from Barbados, Mururoa and Tahiti. Radiocarbon 40(3):108592.

Bar-Yosef O. 2000. The impact of radiocarbon dating on old world Archaeology: past achievements and future expectations. Radiocarbon 42(1):23-39.

Baumgartner S, Beer J, Masarik J, Wagner G, Meynadier L, Synal HA. 1998. Geomagnetic modulation of the ${ }^{36} \mathrm{Cl}$ flux in the GRIP ice core. Science 279:1330-2.

Beck W, Richards D, Herrera S, Calsoyas L, Donahue D, Edwards L, Smart P, Burr G, Jull AJT. 2000. ${ }^{230}$ Th and ${ }^{14} \mathrm{C}$ dating of speleothems from the Bahamas: implications for calibration of the Radiocarbon timescale to 45 ka BP. Abstract. 17th International Radiocarbon Conference, Israel. June 2000.

Bell WT. 1991. Thermoluminescence dates for the Lake Mungo Aboriginal fireplaces and the implications for radiocarbon dating. Archaeometry 33:43-50.

Bischoff JL, Ludwig K, Garcia JF, Carbonell E, Vaquero M, Stafford TW, Jull AJT. 1994. Dating of the basal Aurignacian sandwich at Abric Romani (Catalunya, Spain) by radiocarbon and uranium-series. Journal of Archaeological Science 21:541-51.

Burr GS, Beck JW, Taylor FW, Récy J, Edwards RL, Cabioch G, Corrège T, Donahue DJ, O’Malley JM. 1998. A high resolution radiocarbon calibration between 11,700 and 12,400 calendar years BP derived from ${ }^{230} \mathrm{Th}$ ages of corals from espiritu Santo Island, Vanuatu. Radiocarbon 40(3):1093-105.

Castagnoli CG, Albrecht A, Beer J, Bonino G, Shen C, Callegari E, Taricco C, Ditrich-Hannen B, Kubik P, Suter M, Zhu GM. 1995. Evidence for enhanced ${ }^{10} \mathrm{Be}$ deposition in Mediterranean sediments $35 \mathrm{kyr}$ BP. Geophysical Research Letters 22:707-10.

Chappell J, Veeh HH. 1978. ${ }^{230} \mathrm{Th} /{ }^{234} \mathrm{U}$ age support of an interstadial sea level of $-40 \mathrm{~m}$ at $30,000 \mathrm{yr}$ BP. Nature 276:602-4.

de Geer G. 1912. A geochronology of the last 12,000 years. C R 11th International Geological Congres 1910. Stockholm. p 241-53.

Farrand WR. 1994. Confrontation of geological stratigraphy and radiometric dates from Upper Pleistocene sites in the Levant. In: Bar-Yosef O, Kra RS, editors. Late Quaternary Chronology and Paleoclimates of the Eastern Mediterranean. Tucson: Radiocarbon. $\mathrm{p}$ 33-53.

Frank M. 2000. Comparison of cosmogenic radionuclide production and geomagnetic field intensity over the last 200,000 years. Phil. Trans. Royal Society of London A358:1089-107.

Geyh MA, Schlüchter C. 1998. Calibration of the ${ }^{14} \mathrm{C}$ time scale beyond 22,000 BP. Radiocarbon 40(1):475-82.

Goslar T. 1998. Floating varve chronology of Lake Gosciaz. In: Ralska-Jasiewiczowa M, Goslar T, Madeyska T, Starkel L, editors. Lake Gosciaz, central Poland, a monographic study. Polish Academy of Sciences. $\mathrm{p}$ 97.

Guyodo Y, Valet JP. 1996. Relative variations in geomagnetic intensity from sedimentary records: the past 200 thousand years. Earth and Planetary Science Letters 143:23-36.

Hajdas I, Zolitschka B, Ivy-Ochs SD, Beer J, Bonani G, Leroy SAG, Negendank JW, Ramrath M, Suter M. 1995. AMS radiocarbon dating of annually laminated sediments from lake Holzmaar, Germany. Quaternary Science Reviews 14:137-43.

Hajdas I, Ivy SD, Beer J, Bonani G, Imboden D, Lotter AF, Sturm M, Suter M. 1993. AMS radiocarbon dating and varve chronology of Lake Soppensee: 6000 to $12000{ }^{14}$ C years BP. Climate Dynamics 9:107-16.

Holmgren K, Lauritzen SE, Possnert G. $1994 .{ }^{230} \mathrm{Th} /{ }^{234} \mathrm{U}$ and ${ }^{14} \mathrm{C}$ dating of a Late Pleistocene stalagmite in Lobatse II cave, Botswana. Quaternary Geochronology 13:111-9.

Hughen KA, Overpeck JT, Lehman SJ, Kashgarian M, Southon J, Peterson LC, Alley R, Sigman DM. 1998a. Deglacial changes in ocean circulation from an extended radiocarbon calibration. Nature 391:65-8.

Hughen KA, Overpeck JT, Lehman SJ, Kashgarian M, Southon J, Peterson LC. 1998b. A new ${ }^{14}$ C calibration dataset for the Last Deglaciation based on marine varves. Radiocarbon 40(1):483-94.

Huxtable J, Aitken MJ. 1977. Thermoluminescent dating of Lake Mungo geomagnetic polarity excursion. $\mathrm{Na}$ ture 265:40-1.

Kitagawa H, van der Plicht J. 1998a. Atmospheric radiocarbon calibration to 45,000 yr BP: Late Glacial fluctuations and cosmogenic isotope production. Science 279:1187-90.

Kitagawa H, van der Plicht J. 1998b. A 40,000 year varve chronology from Lake Suigetsu, Japan: extension of the ${ }^{14} \mathrm{C}$ calibration curve. Radiocarbon 40(1):505-15.

Kromer B, Spurk M, Remmele S, Barbetti M, Toniello V. 1998. Segments of atmospheric ${ }^{14} \mathrm{C}$ change as derived from Late Glacial and Early Holocene floating treering series. Radiocarbon 40(1):351-8.

Kromer B, Spurk M. 1998. Revision and tentative extension of the tree-ring based ${ }^{14} \mathrm{C}$ calibration, 920011,855 cal BP. Radiocarbon 40(3):1117-25.

Lin JC, Broecker WS, Anderson RF, Hemming S, Rubenstone JL, Bonani G. 1996. New ${ }^{230} \mathrm{Th} / \mathrm{U}$ and ${ }^{14} \mathrm{C}$ Ages from lake Lahontan carbonates, Nevada, USA, and a discussion of the origin of initial Thorium. Geochimica et Cosmochimica Acta 60:2817-32.

Lin JC, Broecker WS, Hemming SR, Hajdas I, Anderson RF, Smith GI, Kelley M, Bonani G. 1998. A reassessment of U-Th and ${ }^{14} \mathrm{C}$ ages for Late Glacial High-Fre- 
quency Hydrological Events at Searles Lake, California. Quaternary Research 49:11-23.

Lomitschka M, Mangini A. 1999. Precise Th/U-dating of small and heavily coated samples of deep sea corals. Earth and Planetary Science Letters 170:391-401.

McHargue LR, Damon PE, Donahue DJ. 1995. Enhanced cosmic-ray production of ${ }^{10} \mathrm{Be}$ coincident with the Mono Lake and Laschamp geomagnetic excursions. Geophysical Research Letters 22:659-62.

Mellars P. 2000. Châtelperronian chronology and the case for the Neanderthal/modern human 'acculturation' in western europe. Current Anthropology. Forthcoming.

Mellars P, Otte M, Straus L, Zilhao J, D’Errico F. 1999. The Neanderthal problem, continued. CA forum on theroy in Anthropology. Current Anthropology 40(3):341-64.

Mook WG. 1986. Business meeting (12th International Radiocarbon Conference). Radiocarbon 28(2A):799.

Mook WG, van der Plicht J. 1999. Reporting ${ }^{14} \mathrm{C}$ activities and concentrations. Radiocarbon 41(3):227-39.

Prescott JR, Smith MA. 1993. Comparison of thermoluminescence and ${ }^{14} \mathrm{C}$ dates as an indicator of cosmic ray intensity variations. Papers of the 23rd International Cosmic Ray Conference. Calgary. p 838-41.

Raisbeck GM, Yiou F, Fruneau M, Loiseaux JM, Lieuvin M, Ravel JC, Lorius C. 1981. Cosmogenic ${ }^{10} \mathrm{Be}$ concentrations in Antartic ice during the past 30,000 years. Nature 292:825-6.

Readhead ML. 1988. Thermoluminescence dating study of quartz in aeolian sediments from Southeastern Australia. Quaternary Science Reviews 7:257-64.

Renne PR, Karner DB, Ludwig KR. 1998. Absolute ages aren't exactly. Science 282:1840-1.

Richter D, Waiblinger J, Rink WJ, Wagner GA. 2000. Thermoluminescence, electron spin resonance and ${ }^{14} \mathrm{C}$-dating of the Late Middle and Early Upper Palaeolithic site of Geissenklösterle Cave in southern Germany. Journal of Archaeological Science 27:71-89.

Roberts RG, Jones R, Smith MA. 1990. Thermoluminescence dating of a 50,000 year old human occupation site in northern Australia. Nature 345:153-6.

Sikes EL, Samson CR, Guilderson TP, Howard WR. 2000. Old Radiocarbon ages in the southwest Pacific Ocean during the last glacial period and deglaciation. Nature 405:555-9.

Southon J, Hughen K, Herring C, Lehman S, Overpeck J. 2000. A detailed ${ }^{14} \mathrm{C}$ calibration for the Bølling-Allerød-Younger Dryas. Abstract. 17th International Radiocarbon Conference, Israel. June 2000.

Spurk M, Friedrich M, Hofmann J, Remmele S, Frenzel B, Leuschner H, Kromer B. 1998. Revisions and extensions of the Hohenheim Oak and Pine chronologies: new evidence about the timing of the Younger Dryas/ Preboreal transition. Radiocarbon 40(3):1107-16.

Stuiver M. 1970. Long term ${ }^{14} \mathrm{C}$ variations. In: Olsson IU, editor. Radiocarbon Variations And Absolute
Chronology. Proceedings of the 12th Nobel Symposium; 1970; Uppsala University, Sweden. p 197-213.

Stuiver M, Kromer B, Becker B, Ferguson CW. 1986. Radiocarbon age calibration back to 13,300 years BP and the ${ }^{14} \mathrm{C}$ age matching of the German Oak and US Bristlecone Pine chronologies. Radiocarbon 28(2B):969-79.

Stuiver M, Kra RS, editors. 1986. Calibration issue. Radiocarbon 28(2B):805-1030.

Stuiver M, Long A, Kra RS, editors. 1993. Calibration issue. Radiocarbon 35(1):1-244.

Stuiver M, van der Plicht J, editors. 1998. INTCAL98, Calibration issue. Radiocarbon 40(3):1041-164.

Stuiver M, Reimer PJ, Bard E, Beck JW, Burr GS, Hughen KA, Kromer B, McCormac G, van der Plicht J, Spurk M. 1998. INTCAL98 radiocarbon age calibration, 24,000-0 cal BP. Radiocarbon 40(3):104184.

Tauber H. 1970. The Scandinavian varve chronology and C14 dating. In: Olsson IU, editor. Radiocarbon variations and absolute chronology. Proceedings of the 12th Nobel Symposium; 1970; Uppsala University. p 173-96.

van Andel TH. 1998. Middle and Upper Paleolithic environments and the calibration of ${ }^{14} \mathrm{C}$ dates beyond 10,000 BP. Antiquity 72:26-33.

Voelker AHL, Sarnthein M, Grootes PM, Erlenkeuser H, Laj C, Mazaud A, Nadeau MJ, Schleicher M. 1998. Correlation of marine ${ }^{14} \mathrm{C}$ ages from the Nordic seas with the GISP2 isotope record: implications for the ${ }^{14} \mathrm{C}$ calibration beyond $25 \mathrm{ka}$ BP. Radiocarbon 40(1):517-34.

Vogel JC, Kronfeld J, 1997. Calibration of radiocarbon dates for the Late Pleistocene using U/Th dates on stalagmites. Radiocarbon 39(1):27-32.

Wagner G, Beer J, Laj C, Kissel C, Masarik J, Muscheler R, Synal HA. 2000. Chlorine-36 evidence for the Mono Lake event in the Summit GRIP ice core. Earth and Planetary Science Letters 181:1-6.

Wohlfarth B. 1996. The chronology of the Last Termination: a review of high-resolution terrestrial stratigraphies. Quaternary Science Reviews 15:267-84.

Yiou F, Raisbeck GM, Baumgartner S, Beer J, Hammer C, Johnsen S, Jouzel J, Kubik P, Lestringuez J, Stievenard M, Suter M, Yiou P. 1997. Beryllium 10 in the Greenland Ice Core Project ice core at Summit, Greenland. Journal of Geophysical Research 102(C12):26,78394.

Zbinden H, Andree M, Oeschger H, Ammann B, Lotter A, Bonani G, Wölfli W. 1989. Atmospheric radiocarbon at the end of the Last Glacial: an estimate based on AMS radiocarbon dates on terrestrial macrofossils from lake sediments. Radiocarbon 31(3):795-804.

Zhu R, Pan Y, Liu Q. 1999. Geomagnetic excursions recorded in Chinese loess in the last 70,000 years. Geophysical Research Letters 26(4):505-8. 